\title{
National Engineers Week: Reaching out to the Engineers of the Future
}

\author{
Lynne Robinson
}

Editor's Note: A more comprehensive version of this article can be found on the Materials@ TMS web site.

Nanoaccelerometers, embedded within sewer pipes, use a weighted silicon shaft to determine changes in wastewater flow. Roadways incorporate solar thin films to provide an additional energy source to a city. A zinc oxide nanobelt coated with multilayer polymers monitors temperatures within a lunar colony's synthetic atmosphere.

As sophisticated as these concepts are, you won't find them on the drawing boards of any cutting-edge laboratories. Instead, try the imaginations of middle school students who discovered the creativity and excitement of engineering in the National Engineers Week Future City Competition last year. For 2009, more than 30,000 students, working with volunteer engineer-mentors, are focusing on conserving and reusing water. Since January, they have been presenting their solutions, designs, and models at regional competitions, with the winners heading to Washington D.C. for the 17th annual Future City National Finals during National Engineers Week, February 16-18.

While Future City is a complex, nationally coordinated initiative, many notable Engineers Week efforts are of the grassroots variety. The Illinois Institute of Technology in Wheaton, for instance, is opening its doors to the community on February 21 for its annual Engineers Week Expo. Staffed by volunteers from local engineering societies, educational institutions, and businesses, the Expo features interactive displays and presentations designed to show how math and science impact everyday life. Other organizations take a more individualized approach by participating in such Engineers Week activities as Introduce a Girl to Engineering Day on February 19. A number of engineering professionals and educators are also using Engineers Week materials for their own outreach, including Scout programs, plant tours, and spaghetti bridge-building competitions.

According to Kathryn A. Gray, Engineers Week 2009 Chair, all of these efforts rely on engineers who volunteer their time to share their knowledge and enthusiasm for their fields. "Kids of all ages need to know that engineering is about turning ideas into reality and shaping the future," she said. "Together we can make a difference, improve the public image of engineers and our profession, and encourage future generations of engineers along the way."

To underscore the importance of student outreach to the future of the engineering profession, Engineers Week 2009 will launch the Million Hours Challenge. As the name implies, the Challenge intends to document one million volunteer hours related to science, technology, engineering, and mathematics (STEM) education by encouraging engineers not only to contribute their time, but also to log it on the Million Hours Web site. (millionhours djangodomain.com/). In addition to quantifying the impact that engineers have on STEM outreach, Gray said participants can "take pride in seeing the number grow, and in witnessing the number of lives that have been changed in a positive way."

A related initiative for Engineers Week 2009 focuses on encouraging engineers to use the strategies identified in the National Academy of Engineering (NAE) report, Changing the Conversation: Messages for Improving Public Understanding of Engineering, released in June 2008. Based on research funded by the National Science Foundation, the report concluded that young people are more attracted to the field when creativity, teamwork, and opportunities to make a difference are highlighted over technical skills or personal benefits. Gray said having engineers speak with a unified voice on the benefits of their profession could increase interest in engineering careers among young people.

National Engineers Week began as an outreach of the National Society of Professional Engineers in 1951, but has grown into a coalition of more than 100 professional societies, corporations, and government agencies, organized under the auspices of the National Engineers Week Foundation. Besides Engineers Week, the Foundation has been involved with a number of other educational outreach efforts, including two popular PBS series, Design Squad and Cyberchase. It also serves as the secretariat for the Extraordinary Women Engineers Project, anchored by Engineer Your Life, an online guide to engineering for high school girls, parents, teachers, and engineer volunteers.

Priorities have evolved along with the organization over the years, with current ones focused on ensuring diversity in the field and promoting pre-college literacy in math and science.

Gray, who has been involved with Engineers Week since college, said the Foundation's most significant contribution has been enabling the engineering community "to rally around an initiative and cooperate and collaborate on issues significant to the future of our profession." The ultimate goal, she said, is "making every week Engineers Week to help feed the engineering pipeline so our country can remain a competitor in the global market."

Lynne Robinson is the news writer for Materials Technology@TMS. 